\title{
Harvesting and threshing of maize with combine harvester
}

\section{AJAIB SINGH AND KULDEEP SINGH BHULLAR}

Received : 21.06.2016; Accepted : 30.09.2016

See end of the Paper for authors' affiliation

Correspondence to :

\section{AJAIB SINGH}

Krishi Vigyan Kendra, Bahowal, HOSHIARPUR (PUNJAB) INDIA

$\underline{\text { Email : as.ajaib82@gmail.com }}$
-ABSTRACT : This study was conducted to evaluate the performance of maize combines having different types of headers i.e. snap roll type header and cutter bar type header. The mean forward speed and mean field capacity for cutter bar type header type header was $2.10 \mathrm{~km} / \mathrm{hr}$ and $0.30-0.40$ $\mathrm{ha} / \mathrm{hr}$, respectively while mean forward speed and mean field capacity for snap roll type header was $1.50 \mathrm{~km} / \mathrm{hr}$ and $0.20-0.30 \mathrm{ha} / \mathrm{hr}$, respectively. Shattering loss in snap roll type header combine was 12.50 to 18.50 per cent while shattering loss in case of cutter bar type header was 5.00 to 10.50 per cent.

- KEY WORDS : Snap roll header, Cutter bar header, Maize combine

- HOW TO CITE THIS PAPER : Singh, Ajaib and Bhullar, Kuldeep Singh (2016). Harvesting and threshing of maize with combine harvester. Internat. J. Agric. Engg., 9(2) : 249-251, DOI: 10.15740/HAS/IJAE/9.2/ 249-251. 